\title{
Deep-water Fisheries of the Northeast Atlantic: II Assessment and Management Approaches
}

\author{
P. A. Large \\ Centre for Environment, Fisheries and Aquaculture Science \\ Lowestoft, United Kingdom \\ C. Hammer \\ Federal Research Centre for Fisheries, Institute for Sea Fisheries \\ Hamburg, Germany \\ O. A. Bergstad \\ Institute of Marine Research, Flodevigen Marine Research Station \\ N-4817 His, Norway \\ J. D. M. Gordon \\ Scottish Association for Marine Science \\ Oban, United Kingdom \\ P. Lorance \\ Institut Francais de Recherche pour l'Exploration de la Mer \\ Boulogne-sur-Mer, France
}

\begin{abstract}
Most deep-water fish species are long-lived, slow growing and have low reproductive capacity. These stocks are highly vulnerable to exploitation and can be rapidly depleted with recovery being very slow, often taking decades. In the Northeast Atlantic, a diversity of deep-water fisheries exists for a variety of finfish and shellfish species. The major characteristics of these fisheries are described and the available fisheries, biological and life history data are reviewed. Surplus production and DeLury models are the principal methods currently used in assessing the stocks, although agebased methods, stock reduction models and life history models are likely to be used once sufficient biological data become available. Most of the deep-water fisheries in the Northeast Atlantic have been completely unregulated; the latest stock assessments indicate that nearly all exploited deepwater species are being harvested "outside safe biological limits" and that immediate reductions in catches are needed to avoid stock depletion. Various approaches for managing deep-water fisheries resources are discussed, including the need to harmonize conservation and enforcement measures across management jurisdictions for straddling stocks.
\end{abstract}

Keywords: Assessment, deep-water species, management, Northeast Atlantic

\section{Introduction}

Deep-water ecosystems, including deep-water fishery resources, are highly vulnerable to exploitation (Merrett and Haedrich, 1997; Koslow et al., 2000; Anon., MS 2001a) and deep-water habitats are sensitive and in need of protection (OSPAR, 2000). Experience in the South Pacific has shown that deepwater fish stocks can be quickly depleted (Koslow et al., 2000) and that recovery can be very slow (Anon., MS 2001a). In most cases, reliable information on stock status and fisheries production potential lags considerably behind exploitation. Because of the sensitivity of deep-water stocks and the generally inadequate knowledge of their biology, it has been recommended that initial exploitation rates should be very low (Anon., MS 2001b) and that exploitation should not increase until there is adequate understanding of the ecology and dynamics of these resources.

Formalized collation and examination of fisheries and biological data of Northeast Atlantic deep-water species for assessment purposes began in 1994 when 
the International Council for the Exploration of the Sea (ICES) Study Group on the Biology and Assessment of Deep-Sea Fisheries Resources was first convened (Gordon, MS 1998). In 2000, the group was re-established as the ICES Working Group on the Biology and Assessment of Deep-Sea Fisheries Resources. Since 1994, the Group has reported annually to the ICES Advisory Committee on Fishery Management (ACFM). Much of the information presented in this review has been derived from information contained in the Study/Working Group's reports (Anon., MS 1994, MS 1996, MS 1998, MS 2000a, MS 2001c).

\section{General Review of Deep-water Fisheries in the Northeast Atlantic}

Deep-water fisheries in the Northeast Atlantic are quite diverse. Longline and trawl fisheries predominate, ranging from artisanal fisheries to highly mechanized high-seas operations. Some fisheries are directed at single species but most are mixed fisheries targeting several species. A full description of the deep-water fisheries in the Northeast Atlantic is given in Gordon et al. (2002). In this paper, a brief overview of Northeast Atlantic deep-water fisheries is given using particular fisheries as examples.

The longest established deep-water fisheries are the handline and longline fisheries off a) the Azores catching a range of species including red (blackspot) seabream (Pagellus bogaraveo), alfonsinos (Beryx spp.) and, until recently, kitefin shark (Dalatias licha); b) off Madeira and Portugal primarily targeting black scabbardfish (Aphanopus carbo); and c) off Iceland, Norway and the Faroe Islands harvesting ling (Molva molva) and tusk (Brosme brosme). The longline fisheries for ling and tusk have a very long history but are now prosecuted by highly efficient, mechanized vessels fishing over a wide geographical area in the northern parts of the Northeast Atlantic (Bergstad and Hareide, 1996; Magnússon et al., 1997). Both species have been subjected to increasing levels of fishing effort, and catch rates are now declining in most areas. As an example, international landings of tusk from ICES Division Vb (Faroe Islands) more than tripled from the 1950s to the early-1980s but sharply declined thereafter (Fig. 1). Since 1986, catch rates of tusk by large (>100 GRT) Faroese longline vessels have declined by more than 50\% (Fig. 2; Anon., MS 2000a).

Not all longstanding deep-water fisheries show signs of depletion. An example is the Norwegian trawl

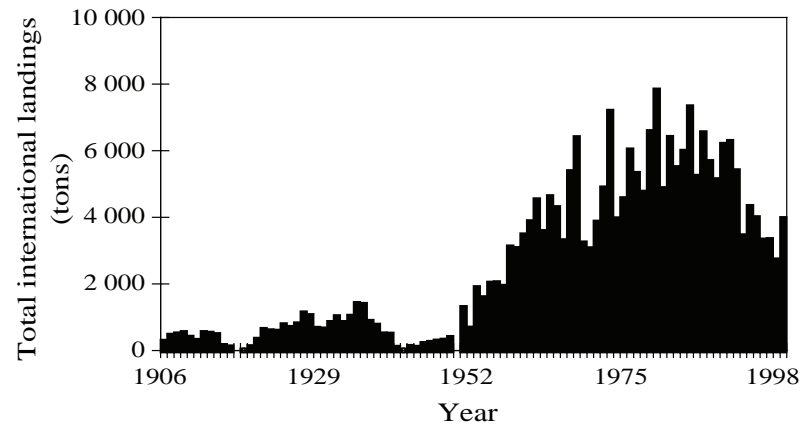

Fig. 1. Total international landings of tusk (Brosme brosme) from the Faroes (ICES Division Vb).

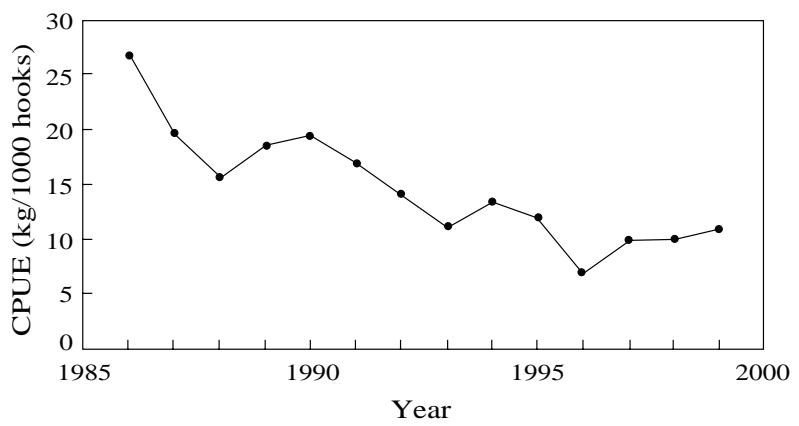

Fig. 2. Catch rates for tusk (Brosme brosme) in ICES Division $\mathrm{Vb}$ by Faroese longline vessels (>100 GRT).

fisheries for greater argentine (Argentina silus) off mid-Norway (Division IIa) and in the Skagerrak (Division IIIa) (Anon., MS 1996; Johannessen and Monstad, 2002). The human consumption fishery began in the mid-1970s and annual landings increased from several hundred tons to over 10000 tons in 1983. Licensing of fishing vessels ( 34 trawlers initially) and annual TACs were implemented in 1982 for the area north of Stadt $\left(62^{\circ} \mathrm{N}\right)$. TACs were eliminated in 1992 but the limited access policy and the use of landings for only human consumption appear to have prevented overfishing. Since 1995, annual landings of greater argentine in the human consumption fishery have been relatively stable, ranging between $6000-9000$ tons.

The bottom trawl fishery for most other deepwater species in the Northeast Atlantic began in the late-1960s when USSR and other eastern bloc countries initiated exploitation of roundnose grenadier (Coryphaenoides rupestris) and alfonsino in international waters to the west of the British Isles and on the Mid-Atlantic Ridge. In the early-1970s, German trawlers harvested blue ling (Molva dypterygia) for a few years. By the mid- to late-1970s, French trawlers, which had traditionally fished along 
the shelf edge for species such as saithe (Pollachius virens), moved into deeper waters to fish for blue ling (Charuau et al., 1995). In the early years of the deepwater bottom trawl fishery, by-catches of roundnose grenadier, black scabbardfish, deep-water sharks and many other less abundant species were discarded. It was only in 1989 that these species began to be landed as a result of a marketing initiative by the French industry. Deep-water trawl fisheries thereafter quickly expanded, partly as result of improving markets but partly due to overfishing of the traditional continental shelf fish stocks and the increasingly restrictive management regime implemented to rectify this situation. In contrast, deep-water stocks were largely unexploited and unregulated.

As fishing skippers became increasingly adept at trawling deep-water grounds, they also took note of developments in other deep-water fisheries around the world. The prosperous orange roughy (Hoplostethus atlanticus) fisheries in the Southern Hemisphere stimulated the search for this species in the Northeast Atlantic by French and Faroese trawlers. Spawning aggregations were located in ICES Subarea VI and a fishery quickly developed in 1991 harvesting about 3500 tons. Subsequently, however, orange roughy landings from Subarea VI declined to less than 200 tons per annum (Fig. 3). Directed fishing effort for orange roughy in this Subarea also declined sharply from about 2650 hours fished in 1991 to less than 200 hours fished per year from 1995 onwards (Anon., MS 2000a). These trends appear to be consistent with a 'mining' approach towards exploitation of most deepwater species. Aggregations are located and then 'pulse-fished' down on a sequential basis. There are also strong indications of other species showing fishery-induced depletion. Landings of red (blackspot)

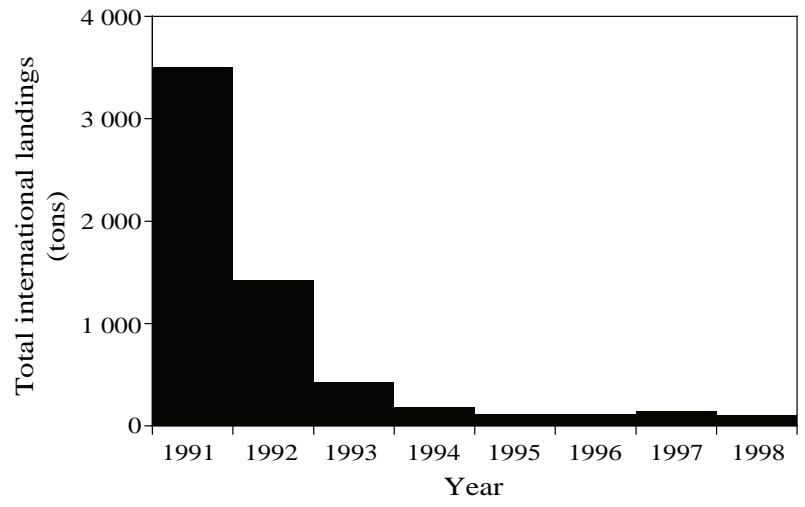

Fig. 3. Total international landings of orange roughy (Hoplostethus atlanticus) from ICES Subarea VI. seabream from ICES Subareas VI, VII and VIII peaked at 24000 tons in 1974 but have since declined to only about 100 tons in recent years (Anon., MS 2000a). Compared to harvest levels observed 20-30 years ago, the fishery has "quasi-collapsed" (Anon., MS 2000a).

Some trawl fisheries target single species and have relatively small by-catches of other species (e.g. fisheries for greater argentine; directed fisheries on spawning aggregations of blue ling and spawning and feeding aggregations of orange roughy). Other trawl fisheries are really mixed species fisheries with targeted stocks changing according to season and fishing depth. For example, in ICES Subarea VI, the French fleet frequently targets roundnose grenadier when not fishing for blue ling - and the quantities of other species landed such as black scabbardfish and deep-water sharks depend on such factors as fishing depth. The Scottish fleet in the same area tends to fish on the upper continental slope and targets anglerfish (Lophius spp.), but lands other deep-water species taken as by-catch. The deep-water crustacean trawl fishery off Portugal targets several species including rose shrimp (Parapenaeus longirostris) and Norway lobster (Nephrops norvegicus). The exploitation of deep-water crustaceans depends on factors such as availability and market price, while the species composition of the by-catch in the deepwater finfish fisheries is a function of fishing depth.

In recent years, deep-water fishing activity in the Northeast Atlantic has continued to increase. Fishing vessels from France, Norway, Spain, Portugal, Russia, Ireland, United Kingdom, Iceland, Faroe Islands, Poland and the Netherlands are now actively involved in deep-water fisheries. Exploratory surveys by commercial fishing vessels continue to identify/locate "new" resources, particularly in international waters on the Hatton Bank and along the Mid-Atlantic Ridge.

A feature of all deep-water fisheries (whether they be longstanding or new, artisanal or mechanized) is that almost all have developed without programs in place to collect biological and fisheries data. Consequently, our understanding of the population dynamics of deep-water species and the impacts of fishing on these resources has lagged considerably behind exploitation.

\section{Availability of Fisheries and Biological Data for Assessments}

Although the quality and quantity of deep-water fisheries and biological data have improved in recent 
years (and has been substantially augmented by information acquired from the European Commission Deep-water Fisheries Project (Gordon, 1999a, 2001b)) for some species - particularly deep-water sharks there are still problems caused by catches being recorded by species groups (Gordon, 1999b). Furthermore, in some cases, only body parts (e.g. livers and oils) are landed. A further concern is the quality of landings data from international waters; some deep-water stocks straddle EEZ, national and international fisheries jurisdictions and a critical need exists to harmonize recording and reporting procedures.

There are also concerns regarding discards. When deep-water fish are captured and brought to the sea surface, the changes in pressure almost guarantee that fish landed on deck and subsequently discarded will not survive. Also, many deep-water species are susceptible to damage by trawls because their skin is not covered by mucus. Thus, a high proportion of fish entering trawls but escaping through the meshes probably die (Connolly and Kelly, 1996; Koslow et al., 2000). However, few discard studies have been conducted on a regular basis. Some short-term investigations of discarding in the French and Scottish trawl fisheries indicate that discard rates vary widely among species (Blasdale and Newton, MS 1998; Dupouy et al., MS 1998). Given the general lack of time-series data on discards, estimating the total catch of deep-water species is virtually impossible. This not only affects the quality of the stock assessments but since discarding and trawl escapees also include noncommercial species, it is therefore difficult to accurately evaluate the impacts of fishing on the Northeast Atlantic deep-water ecosystem.

Although biological studies of deep-water species have increased during the last decade (Gordon, 1999a; Magnússon et al., 1997; Menezes et al., MS 2001), knowledge of biological processes such as growth, feeding, maturation and fecundity still lags behind that of commercially exploited shelf-based species. Also, little is known about recruitment processes and variation, stock identity, fish migration and fish behavior. The recent development of remote tagging devices for deep-water fish (coupled with the use of data storage tags) should allow progress to be made in understanding behavior and movement/migration patterns. Although considerable progress has been made in length and age sampling of commercial deepwater landings, there is still scope for significant improvement for many species. Where fisheries sampling data are available, the time-series remain short for assessment purposes (frequently less than 5 years) and for some species, sampling has not yet been fully implemented or remains incomplete.

Age-disaggregated landings data are rare for deep-water fishes. Age determination of deep-water species is difficult as calcified structures such as otoliths frequently display a large number of rings making age interpretation and validation difficult. Amongst the deep-water species currently assessed in the Northeast Atlantic, the greatest progress in age determination has been made with roundnose grenadier, orange roughy, ling, black scabbardfish and blue ling. Of these species, age determination of roundnose grenadier and ling is the most straightforward. Interpretation of the annuli in otoliths of these species is reasonably clear (Bergstad, 1995; Kelly et al., 1997) and for roundnose grenadier is partly validated (Gordon and Swan, 1996). Age determination of blue ling is not as straightforward (Bergstad et al., 1998), and inconsistencies exist in ageing results between different countries. There is consensus, however, that blue ling recruit to the fishery at 6 to 8 years of age and that most of the catch is comprised of fish between ages 8-20. Unvalidated age estimates suggest that black scabbardfish, unlike most other deep-water fishes, have a relatively rapid growth rate and a longevity of either 8-12 years (from whole otoliths) or $\sim 25$ years (from sectioned otoliths) (Morales-Nin and SenaCarvalho, 1996; Santos, MS 2000). Radiometric ageing has confirmed the longevity of orange roughy (up to 125 years) (Fenton et al., 1991; Francis, 1995; Smith et al., 1995), but age-based assessments of this species have been questioned because in some Southern Hemisphere stocks catch length compositions have changed little after 20 years of exploitation (Clark et al., 2000; Clark, 2001).

Few studies exist on the stock-structure of deepwater fish species in the Northeast Atlantic (Anon., 2000a, Menezes et al., MS 2001). For assessment purposes, stock units have been defined using current knowledge of species distribution and similarity of catch-rate trends among ICES statistical areas (Anon., MS 1998). Thus, current stock units represent individual or groups of ICES Subareas and occasionally ICES Divisions. This is far from ideal as the ICES statistical areas were devised for the continental shelf and, in many instances, are completely inappropriate for deep-water fisheries. For example, ICES Subarea VI is divided into two 
Divisions: Division VIa covers the shelf along the continental margin, and Division VIb encompasses the Rockall Plateau. Division VIa, however, includes both the Rockall Trough and a part of the FaroeShetland Channel. The deep-water fish faunas of these two areas have little in common (Gordon, 2001a). Division VIb extends westwards from the Rockall Plateau and is contiguous with Subarea XII at longitude $18^{\circ} \mathrm{W}$. This Division therefore bisects the Hatton Bank, which is in international waters and has a rapidly developing deep-water fishery. Subarea XII covers a vast area of the northeastern Atlantic and includes large sections of the Mid-Atlantic and Reykjanes Ridges. However, a proportion of the landings from Subarea XII cannot be readily attributed to the Hatton Bank and have therefore been excluded from the assessments of the Rockall area stocks. Thus, a critical need exists to reconfigure some of the ICES statistical areas so that they are biologically meaningful in terms of the distribution of deep-water species.

Further studies on genetic identity of deep-water stocks are needed (Anon., MS 2000b), and alternative methods such as otolith microchemistry may be useful for stock discrimination. An otolith microchemistry study has been initiated for black scabbardfish (Swan et al., MS 2001) and similar projects are underway for other deep-water demersal fishes. DNA studies will also be useful, and population genetics work on red (blackspot) seabream and alfonsinos using DNA analyses are now underway in the Azores.

Estimates of natural mortality (M) are required for some of the methods currently used to assess deepwater stocks in the Northeast Atlantic. Estimates of $\mathrm{M}$ are currently available from two sources: a) from catch curves using data collected pre-exploitation (from exploratory surveys); and b) by using the equation $\mathrm{M}=\log _{\mathrm{e}} 100 /$ maximum age, where maximum age is the age to which $1 \%$ of the population survives in an unexploited stock (Annala, MS 1993).

There is almost a total lack of fishery-independent surveys designed to acquire time-series data on deepwater stocks for use in assessments. To date, most surveys have either been exploratory in nature or designed to collect biological data.

The paucity of research vessel survey data has meant that assessments have had to rely on abundance indices derived from commercial catch and effort data. Most of the current assessments of Northeast Atlantic deep-water stocks use annual abundance indices derived from catch/effort data from the French deepwater trawl fleet. A part of this fleet has been relatively constant in terms of engine power, fishing gear, and the number of vessels exploiting deep-water species. For each species, catch and effort data are filtered to exclude trips directed at other species (Biseau, 1998). The data are then analyzed using a multiplicative model that includes factors for month and ICES Subarea, weighted by fishing effort. Model estimates of annual standardized catch-per-unit-effort (CPUE) are then derived and used as abundance indices in the assessments (Lorance and Dupouy, 2001). While these indices are considered reasonably robust, there are concerns that fishing depth affects CPUE for some species. Although fishing depth is not currently recorded in mandated logbooks, analysis of depth data voluntarily recorded by a single fishing skipper suggests that the effect of depth on CPUE is minor (Girard et al., 2000). However, further studies are required to confirm this. Changes in the spatial distribution of fishing within ICES Subareas may also affect estimates of annual standardized CPUE and this also requires investigation.

\section{Life History Characteristics}

Deep-water fish are typically described as longlived, slow growing, and having low reproductive capacity. However, this description is not applicable to all deep-water fishes as there are some species whose life history characteristics are comparable to continental shelf species. Similarly, orange roughy is often referred to as a typical deep-water species when it is really an extreme form of the type. The ICES Working Group on the Biology and Assessment of Deep-Sea Fisheries Resources recently conducted a review of the life history parameters of Northeast Atlantic deep-water species to determine suitable assessment methods and to identify the relative vulnerability of different species to exploitation (Anon., MS 2001c). Species were ranked according to their longevity, growth rate, natural mortality, fecundity and length/age at first maturity, but only data on longevity and growth rate are presented here (Table 1).

Orange roughy and roundnose grenadier are the longest-lived and slowest growing, while species such as alfonsino and black scabbardfish are comparatively short-lived and exhibit considerably faster growth rates. 
TABLE 1. Deep-water species in the Northeast Atlantic ranked according to (1) longevity and (2) growth rate (summarized from Anon., MS 2001c).

\begin{tabular}{lcc}
\hline \hline Species & $\begin{array}{c}\text { Longevity (years) } \\
\text { (rank in brackets) }\end{array}$ & $\begin{array}{c}\text { Growth rate }\left(k\left(y^{-1}\right)\right) \\
\text { (rank in brackets) }\end{array}$ \\
\hline Orange roughy & $125(1)$ & $0.06-0.07(1)$ \\
Roundnose grenadier & $>60(2)$ & $0.06-0.13(2)$ \\
Deep-water squalid sharks: & Not known & Not known \\
Centroscymnus coelolepis & $60-70(2)$ & Not known \\
Centrophorus squamosus & $30(3)$ & Not known \\
Blue ling & $35(3)$ & $0.17-0.20(4)$ \\
Argentine & $20(4)$ & Not known \\
Ling & $20 ?(4)$ & $0.25(5)$ \\
Tusk & $8-12$ from whole otoliths & $0.10-0.17(3)$ \\
Black scabbardfish & 25 from sections $(4)$ & Not known \\
Red (blackspot) seabream & $16(4)$ & $0.11-0.17(3)$ \\
Greater forkbeard & $15 ?(4)$ & $0.13-0.14(4)$ \\
Alfonsino: & $13(5)$ & \\
Beryx decadactylus & $11(5)$ &
\end{tabular}

\section{Stock Assessment Methods Currently Used and Options for the Future}

Length-based assessment methods, which rely on a strong link between modal length and age structure, are unsuitable for species such as orange roughy (Fig. 4 ), which show no obvious multi-modal structure or modal progression. Age-based methods are also rarely used because of a lack of reliable ageing data for most species. The principal data series available for most exploited deep-water species in the Northeast Atlantic are total international nominal catches, and annual catch and effort data from individual fleets. The main assessment approach is depletion modeling using surplus production and modified DeLury models (Anon., MS 1998, MS 2001c). These models provide estimates of current and virgin exploitable biomass $\left(B_{0}\right)$, from which a 'depletion ratio' can be calculated for each stock ${ }^{1}$.

If time-series of catch data are incomplete, initial population sizes and all subsequent population estimates from the depletion models will be underestimated. The models also assume that the data are from a single stock (i.e. there is no immigration from or emigration to other populations); if this is not the case, the population estimates will be distorted. Depletion methods require an index of relative population size that should vary in relation to temporal changes in stock size (i.e. catchability and fishing
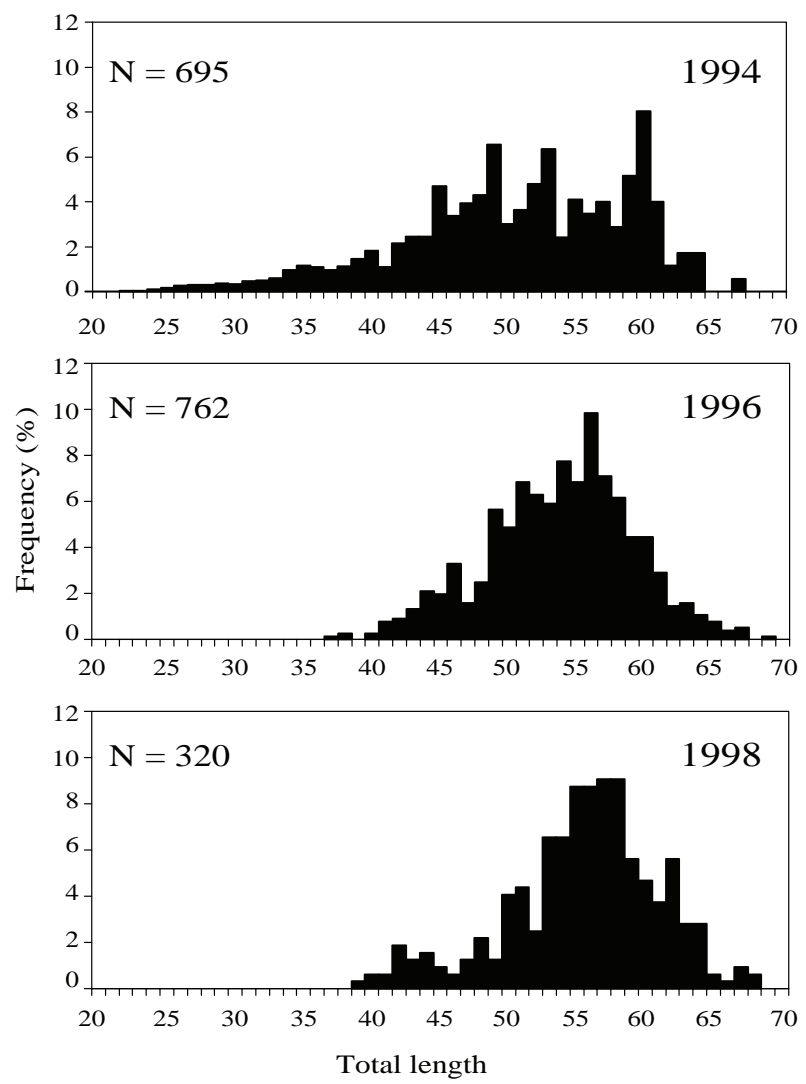

Fig. 4. Length distribution of French landings of orange roughy (Hoplostethus atlanticus) from Subareas VI and II, 1994, 1996 and $1998(N=$ number of fish sampled).

1 Where the fit of these models is poor, smoothed time-series of CPUE from commercial trawlers have been used directly as an index of exploitable biomass and to calculate depletion ratios. 
power effects should be constant). Also, for species occurring in aggregations, such as orange roughy, indices of abundance can be biased if exploitation reduces the size of aggregations rather than fish density (Clark et al., 2000; Clark, 2001). Sequential depletion or 'mining' of such aggregations can also give rise to biased estimates of overall abundance. The modified DeLury model assumes constant recruitment with time, while production models assume that recruitment is determined by current stock size. Both models typically do not consider environmental effects or other factors affecting recruitment. As noted earlier, very little is known about recruitment processes in deep-water fishes. Notwithstanding these concerns, some progress has been made in using these methods to assess the status of deep-water fish stocks in the Northeast Atlantic.

The DeLury model uses time-series of catches (in number of fish) and an index of population abundance (CPUE) to estimate (1) the catchability coefficient $(q)$ of the CPUE index; and (2) the unexploited population size in number $(K)$. The method requires an estimate of $\mathrm{M}$ and of the ratio between the population size at the start of the time-series and the unexploited population size. Sensitivity analysis is used to evaluate a range of error models and assumptions about stock size in the first year as a proportion of virgin biomass. Confidence limits about model parameters and population estimates are calculated by bootstrapping.

The production models used in the assessments are non-equilibrium biomass dynamic models (i.e. they do not assume that stock is in equilibrium with the fishery). The models assume that biomass in the current year is related to biomass in the following year (or several years thereafter) because of growth and recruitment. Time-series of catches (in weight) and an index of population biomass are used to estimate the catchability coefficient of the CPUE index $(q)$, the population production rate $(r)$ and carrying capacity $(K)$. Confidence limits for the model parameters and the population estimates are calculated by bootstrapping. Sensitivity analysis is used to evaluate the effect of error models and the ratio of initial to carrying capacity (defined as the unfished equilibrium stock size). A zero time lag is used since the available timeseries of catch and CPUE are typically too short (frequently $8-10$ years) to reliably explore various time lags in recruitment. It is assumed, therefore, that growth rather than recruitment is the main contributor to biomass production. For some stocks, available CPUE data show a decline across the time period studied (Fig. 5) which may give unreliable results (the so called 'one way trip').

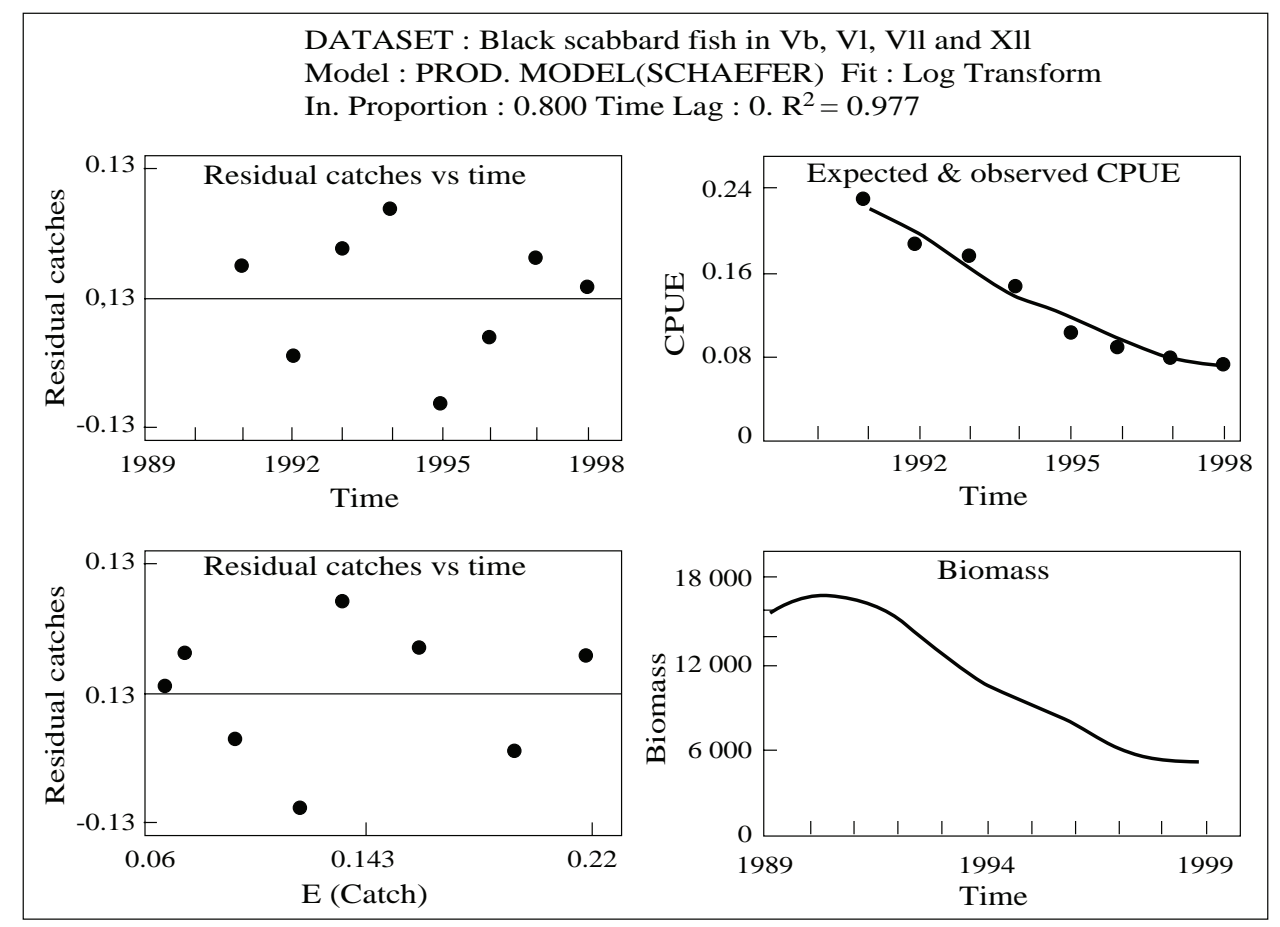

Fig. 5. Black scabbardfish (Aphanopus carbo) in Subareas VI, VII, XII and Division Vb. Schaefer model. 
Production models provide estimates of a) exploitable biomass for the calculation of depletion ratios and b) maximum sustainable yield (MSY). Confidence limits about these values are very wide, suggesting that MSY is currently poorly estimated.

Estimates of MSY have also been derived using the Beddington and Cooke procedure (Beddington and Cooke, 1983), where the ratio MSY/ $B_{0}$ is calculated taking into account $\mathrm{M}$, growth rate ( $k$, in the von Bertalanffy growth equation) and size (or age) at recruitment to the fishery. This procedure is based on equilibrium calculations assuming constant recruitment, and thus potential effects of variable recruitment and reduced recruitment at low spawning stock sizes are not considered.

The estimates of MSY are used in two ways. Firstly, ratios of $\mathrm{MSY} / B_{0}$ highlight potential differences between yield levels that can be expected from slow-growing, long-lived species versus traditional species such as gadoids. For example, Beddington-Cooke ratios of MSY/ $B_{0}$ (Beddington and Cooke, 1983) for a typical gadid species (having an $\mathrm{M}$ of 0.2 and a growth rate of around 0.3) might be $\sim 0.07$ to 0.08 or higher, depending on the age of recruitment to the fishery. In contrast, ratios for deepwater species can be as low as 0.02 or 0.03 . Secondly, estimates of MSY can indicate the likely order of magnitude of sustainable catches (i.e., are sustainable catches likely to approach hundreds - or thousands of tons) (Basson et al., 2002).

Fishery independent estimates of virgin stock biomass have also been derived for roundnose grenadier, blue ling and orange roughy (using the swept area method) from a series of German trawl surveys conducted during 1974 to 1980 (Anon., MS 1998). These surveys were carried out in depths between 400 and $1400 \mathrm{~m}$ and provide pre-exploitation estimates of stock abundance of the three species in ICES Subarea VI and adjacent Divisions VIIb,c.

For some species where the available biological data are limited to only partial length or age compositions from individual years, estimates of total instantaneous mortality rate $(Z)$ have been derived from catch curves. Given (or assuming) a value for $\mathrm{M}$, it has been possible to estimate fishing mortality (F). However, such analyses assume that F, M, q and recruitment have remained constant over time. Consequently, these methods only provide information on the scale of $\mathrm{Z} / \mathrm{F}$, i.e. whether it is high or low, rather than accurate estimates.
In the future, opportunities to use a wider range of assessment methods and to produce more robust evaluations of stock status will depend on improving both the quantity and quality of fisheries and biological data. All countries with deep-water fisheries should collate and furnish detailed catch/effort data and prepare abundance indices for use in assessments. Fishery-independent surveys should also be initiated to obtain a time series of distribution and abundance data. For demersal species, bottom trawl and/or longline gear would be most appropriate, while midwater trawls (probably in conjunction with acoustic surveys), would be suitable for surveying pelagic and semi-pelagic species such as argentines and alfonsinos. Acoustic surveys might best be used to estimate stock biomass of acoustically reflective species such as orange roughy, greater argentine and roundnose grenadier. To better interpret both fishery and survey data, it would also be useful to study gear selectivity and the behavioral responses of deep-water species to fishing and survey gear.

Sufficient times series of catch-at-age data may soon be available for ling at the Faeroes (ICES Division $\mathrm{Vb}$ ) and red (blackspot) seabream in the Azores (ICES Subarea X) to conduct virtual population analyses. Extended survivors analysis (XSA) will probably be used for tuning using catch and effort data from Faroese longliners and from an Azorean longline survey, respectively. The success of these assessments will depend on the reliability of catch data, the quality of age determination, the extent to which catchability is constant in tuning fleets and the assumptions made regarding stock structure. If age determination problems with blue ling can be overcome and biological sampling of roundnose grenadier continues, age-based assessments of these species may be possible within the next five years (Lorance et al., MS 2001).

The use of stock reduction models (sometimes known as delay-difference models) and life history tables to assess deep-water stocks in the Northeast Atlantic should be investigated further. Life history tables can be used for evaluating and projecting stock structure, and can be updated as knowledge increases. Population characteristics such as length composition can be included, and this approach is particularly useful for species such as sharks where age determination is difficult (Heessen, MS 2001). Stock reduction models can be considered as a conceptual hybrid of surplus production and age-based models (Heessen, MS 2001), wherein the basic dynamics of an age-structured population are predicted without requiring annual records of population age structure. 
Stock reduction models have been used extensively to assess deep-water stocks off New Zealand and Australia. However, experience has shown that for some stocks, e.g. orange roughy off New Zealand, a combination of assessment methods (stock reduction models, annual trawl surveys, egg production surveys, acoustic surveys and analyses of commercial CPUE) is more successful than any single technique (Clark, 1996). This will probably also be true for many deep-water stocks in the Northeast Atlantic. In the short term, it is envisaged that depletion models will continue to be used and supplemented, where possible, with stock reduction models, life history models and age-based methods. If data from fishery independent surveys become available, these will provide independent estimates of stock biomass and, in the longer term, furnish abundance indices for use in assessments.

\section{Biological Reference Points}

The life history characteristics of deep-water species should be important determinants of biological reference points. As deep-water species are to varying degrees less productive than species on the continental shelf, sustainable exploitation rates will typically be lower and the time required for stocks to respond to management measures will generally be longer. A second factor influencing the choice of biological reference points is uncertainty, both in assessments and in knowledge of population dynamics. Although research and monitoring of deep-water species in the Northeast Atlantic have increased in recent years, the data available for assessments of deep-water stocks remains sparse in comparison with continental shelf fishery resources. Considering both of these factors, ICES has recommended that the biological reference points developed in 1998 for deep-water stocks should continue to be used (Anon., MS 2001b). These are:

$$
\begin{array}{ll}
F_{\text {lim }}=F_{35 \% S P R} & B_{\text {lim }}=0.2 \times B_{\text {max }} \\
F_{p a}=M & B_{p a}=0.5 \times B_{\text {max }}
\end{array}
$$

For most Northeast Atlantic deep-water stocks, the only information available on $F$ is from catch curves (assuming knowledge of $M$ ) and consequently $F_{\text {lim }}$ and $F_{p a}$ are rarely used. For many stocks, absolute biomass estimates are not available and instead ICES uses biomass indices (e.g. commercial CPUE indices or research vessel survey indices). These indices are denoted by $U$ so that $U_{l i m}$ is an index for $B_{l i m}$, etc. The reference points thus become:

$$
\begin{gathered}
U_{\text {lim }}-0.2 \times U_{\max } \quad \text { (maximum observed biomass } \\
\text { indicator, may be a smoothed index) } \\
U_{p a}-0.5 \times U_{\max }
\end{gathered}
$$

In recent years, ICES has defaulted to this notation for all deep-water stocks in the Northeast Atlantic.

The primary management objective is to implement management measures to maintain $U_{\text {current }}$ $>U_{\mathrm{pa}}$. If $U_{\text {current }}$ is between $U_{p a}$ and $U_{\text {lim }}$, then the stock is considered to be 'outside safe biological limits' and appropriate management measures are recommended (currently a $30 \%$ reduction in exploitation). If $U_{\text {current }}$ is close to $U_{\text {lim }}$, more stringent management measures are recommended (e.g. a reduction in exploitation by $50 \%$ ). When $U_{\text {current }}$ is below $U_{\text {lim }}$, ICES has recommended that directed fisheries be closed and that measures be enacted to reduce/minimize by-catches.

\section{Current State of Deep-water Stocks in the Northeast Atlantic}

The most recent information on the status of deepwater stocks in the Northeast Atlantic was provided by ICES in May 2001 (Anon., MS 2001b) and is summarized in Table 2. Most exploited deep-water species in the Northeast Atlantic are presently considered to be harvested 'outside safe biological limits'. The effect of this harvesting (particularly by trawl gear) on the deep-water ecosystem is also a concern because of the presumed high mortality of both escapees and discards and benthic fauna.

\section{Options for Fisheries Management}

Fishing effort for deep-water species in the Northeast Atlantic has largely been uncontrolled and now most deep-water stocks are 'outside safe biological limits'. To address this situation, ICES recommended (in both 2000 and 2001) an immediate reduction in fishing effort on these stocks (referred to as Category 2 fisheries in Table 3). As well, ICES stated that "fishing should not be allowed to expand faster than the acquisition of information necessary to provide a basis for sustainable exploitation" (Anon., MS 2001a) and advised that "New fisheries should be permitted only when fisheries expand very slowly, and are accompanied by programs to collect data which allow evaluation of stock status" 
TABLE 2. Current state of deepwater stocks in the Northeast Atlantic (Anon., MS 2001b).

\begin{tabular}{|c|c|c|c|}
\hline Species & $\begin{array}{l}\text { ICES Subarea/ } \\
\text { Division }\end{array}$ & $\begin{array}{l}\text { Assessment } \\
\text { type }\end{array}$ & State of stock \\
\hline $\begin{array}{l}\text { Blue ling } \\
\text { (Molva dypterygia) }\end{array}$ & $\begin{array}{l}\text { Mainly II,V, VI, } \\
\text { VII \& XII }\end{array}$ & CPUE & $\begin{array}{l}\text { Below } U_{\text {lim }} \text { in V, VI \& VII. } \\
\text { Unknown in other areas. }\end{array}$ \\
\hline Ling (Molva molva) & Almost all areas & $\begin{array}{l}\text { CPUE } \\
\text { Catch curves }\end{array}$ & $\begin{array}{l}\text { Uncertain and variable across its } \\
\text { range. Below } U_{p a} \text { in some areas. }\end{array}$ \\
\hline Tusk (Brosme brosme) & $\begin{array}{l}\text { Mainly IIa, IV, V } \\
\text { \&VI }\end{array}$ & CPUE & $\begin{array}{l}\text { Stock decline in all areas except Va. } \\
\text { Probably below } U_{\text {lim }} \text { in } \mathrm{Vb} \text {. }\end{array}$ \\
\hline Roundnose grenadier & I, II, III, IV, Va, & DeLury & Near to $U_{p a}$ in Vb, VI \& VII. \\
\hline (Coryphaenoides rupestris) & $\begin{array}{l}\text { Vb, VI \& VII,VIII, } \\
\text { IX, X }\end{array}$ & Schaefer & Unknown in other areas. \\
\hline $\begin{array}{l}\text { Black scabbardfish (Aphanopus } \\
\text { carbo) }\end{array}$ & $\begin{array}{l}\text { Vb, VI,VII, VIII, } \\
\text { IX, X \& XII }\end{array}$ & $\begin{array}{l}\text { DeLury } \\
\text { Schaefer }\end{array}$ & $\begin{array}{l}\text { Below } U_{p a} \& \text { possibly below } U_{l i m} \text { in } \\
\text { V, VII,VII \& XII. Uncertain in other } \\
\text { areas. }\end{array}$ \\
\hline $\begin{array}{l}\text { Greater Argentine } \\
\text { (Argentina silus) }\end{array}$ & $\begin{array}{l}\text { I, II, III, IV, V, VII } \\
\& \text { VII }\end{array}$ & $\begin{array}{l}\text { No } \\
\text { assessment }\end{array}$ & Unknown \\
\hline $\begin{array}{l}\text { Orange roughy (Hoplostethus } \\
\text { atlanticus) }\end{array}$ & $\begin{array}{l}\text { Va, Vb, VI, } \\
\text { VII, IX \& XII }\end{array}$ & $\begin{array}{l}\text { DeLury } \\
\text { Schaefer }\end{array}$ & $\begin{array}{l}\text { Below } U_{\text {lim }} \text { in VI } \\
\text { Unknown in other areas. }\end{array}$ \\
\hline Red (blackspot) Seabream & IX, $X \&$ partly in & No & Unknown in X. \\
\hline (Pagellus bogaraveo) & VI,VII \&VIII & assessment & Possibly below $U_{\text {lim }}$ elsewhere. \\
\hline $\begin{array}{l}\text { Greater forkbeard } \\
\text { (Phycis blennoides) }\end{array}$ & $\begin{array}{l}\text { All areas but } \\
\text { mainly VI, VII,VIII } \\
\& \text { IX }\end{array}$ & $\begin{array}{l}\text { No } \\
\text { assessment }\end{array}$ & Unknown \\
\hline $\begin{array}{l}\text { Alfonsino } \\
\text { (Beryx splendens })\end{array}$ & Mainly X & $\begin{array}{l}\text { No } \\
\text { assessment }\end{array}$ & Unknown \\
\hline Deepwater squalid sharks & $\begin{array}{l}\text { Va, Vb, VI, VII, } \\
\text { VIII, IX \& X }\end{array}$ & $\begin{array}{l}\text { DeLury } \\
\text { Schaefer }\end{array}$ & No information given by ACFM \\
\hline
\end{tabular}

(collectively referred to as Category 1 fisheries in Table 3). The ICES advice on permitting was subsequently clarified to also apply to situations where existing fisheries expand into unexploited areas and when significant changes occur in the fisheries (i.e. the introduction of new gears or fleets) (Anon., MS 2001b).

In response to the ICES advice, the European Commission (in December 2001) proposed to introduce catch limitations (Total Allowable Catches, TACs) in 2002 on 11 deep-water fish species (alfonsinos, black scabbardfish, blue ling, forkbeards, greater silver smelt, ling, orange roughy, red seabream, tusk, and deep sea sharks). Additional measures were proposed by the Commission in March 2002 that would: a) require vessels exploiting deepwater resources to have deep-water fishing permits; b) cap/restrict the deep-water fishing capacity of all EU Member States; c) require deep-water permitted vessels to possess a fully operational satellite tracking device to ensure the enforcement of management measures; d) designate specific ports where permitted vessels would have to land their catches of deep-water species; and e) initiate collection of representative data adequate for the assessment and management of deepwater fish stocks by deploying scientific observers aboard vessels having deep-water fishing permits. However, none of the Commission's proposals have yet received approval and been adopted by the Council of Fisheries Ministers.

For long-lived, slow-growing species such as orange roughy, sustainable yields may only be $1-2 \%$ per year of the pre-exploitation biomass. Furthermore, the rate of rebuilding after depletion may be as low as $2.5 \%$ of virgin biomass per year (Anon., MS 2001b). Given these low productivity and recovery rates, it is essential that any management regimen enacted for deep-water stocks be capable of achieving these objectives. The following section discusses the advantages and disadvantages of different management approaches to achieve sustainable catches and promote resource recovery of deep-water species. 
TABLE 3. Summary of the ICES advice for deepwater stocks in the Northeast Atlantic (Anon., MS 2001b).

\begin{tabular}{|c|c|c|}
\hline Species/stock & $\begin{array}{c}\text { Category } 1 \\
\text { Developing new fisheries }\end{array}$ & $\begin{array}{l}\text { Category } 2 \\
\text { Fully or overexploited }\end{array}$ \\
\hline Blue ling & & $\begin{array}{l}\text { All populations } \\
\text { No directed fisheries for this species and } \\
\text { measures be implemented to reduce/mimimize } \\
\text { catches in mixed fisheries. }\end{array}$ \\
\hline Ling & & $\begin{array}{l}\text { All populations } \\
\text { Fishing effort be reduced by } 30 \%\end{array}$ \\
\hline Tusk & $\begin{array}{l}\text { Hatton bank fishery (part of } \\
\text { Subareas VI \& XII) }\end{array}$ & $\begin{array}{l}\text { All areas except Hatton Bank } \\
\text { Fishing effort be reduced by } 30 \%\end{array}$ \\
\hline Roundnose grenadier & $\begin{array}{l}\text { All fisheries outside Sub- } \\
\text { areas VI, VII \& Vb }\end{array}$ & $\begin{array}{l}\text { Subareas VI, VII \& Vb } \\
\text { Fishing effort be reduced by } 50 \%\end{array}$ \\
\hline Black scabbardfish & Fishery in Subarea X & $\begin{array}{l}\text { Subareas VI, VII, VII, XII and possibly IX } \\
\text { Fishing effort be reduced by } 50 \%\end{array}$ \\
\hline Greater Argentine & All fisheries & \\
\hline Orange roughy & All fisheries except in VI & $\begin{array}{c}\text { Subarea VI } \\
\text { Fishing effort be reduced by } 50 \%\end{array}$ \\
\hline Red (blackspot) seabream & & All populations \\
\hline Greater forkbeard & All fisheries & \\
\hline Alfonsinos & All fisheries & \\
\hline Deepwater sqalid sharks & All fisheries & \\
\hline
\end{tabular}

Managing deep-water fisheries in the Northeast Atlantic using total allowable catches (TACs) as a primary tool has several advantages and disadvantages. TACs can be introduced quickly and provide a relatively straightforward method of allocating catches between participating countries (i.e. national quotas). However, the effectiveness of TACs depends on the quality of landings data and on enforcement. Also, many deep-water species are harvested in mixed fisheries, where TACs for different species are usually taken at different rates. Under these conditions, fleets tend to harvest species with available quota while discarding species whose TACs have already been attained. Because of the low survival of discards and the high mortality inflicted on escapees from trawls, continued fishing under these circumstances generates a high mortality on all fish taken, including noncommercial species. Thus, zero TACs for individual stocks would be most effective in single species fisheries having little, if any, by-catches. For mixed fisheries, the entire fishery may have to be closed, or exploitation restricted to time/area windows or to highly selective gear that minimize by-catch.

Some deep-water stocks in the Northeast Atlantic straddle EEZ and international waters and are therefore distributed amongst different fisheries jurisdictions. If TACs for these stocks were implemented unilaterally by one of the management authorities (e.g. EU), catches might be misreported to an area outside this management jurisdiction (i.e. international waters). Even if the North-East Atlantic Fisheries Commission (NEAFC), the EU and national governments jointly imposed TACs for deep-water species, catches in international waters would still likely be underestimated because harvests outside national EEZs have typically been underreported (Anon., MS 2001a). These concerns could be addressed by: a) having independent observers aboard vessels fishing in international waters; b) implementing improving reporting procedures; and c) introducing satellite monitoring. 
Managing deep-water fisheries in the Northeast Atlantic via input controls regulating fishing effort (i.e. vessel licensing and restrictions on the number of days at sea) also has various advantages and disadvantages. Such a regimen would probably be easier to enforce than catch quotas and could be referenced to different ICES Subareas using vessel monitoring systems. However, unavoidable mortality in mixed fisheries would still be problematic. Given the unfavorable status of many Northeast Atlantic deep-water stocks and the pressing need for management measures to avoid stock depletion, a possible drawback of an effort regulation scheme is that it might take considerable time to design and implement.

Technical measures such as mesh size regulations and selectivity grids are unlikely to be effective for deep-water fisheries because of the very high mortality of escapees. Closed areas are also unlikely to be effective because most deep-water species have a wide geographical range. Nonetheless, closed areas may be appropriate for protecting spawning concentrations (i.e. for blue ling) and species associated with topographical features (e.g. orange roughy and seamounts). However, such features can be geographically widely scattered and may require a patchwork of closed areas that would be difficult to monitor and effectively enforce. Trawl exclusion areas (and even no-take zones) may be necessary to protect cold-water coral reefs and seamounts where fish populations are heavily depleted.

The decision on what regulatory approach is enacted in the Northeast Atlantic lies with the European Commission, NEAFC, and national governments. However, it is vital that controls be put in place soon as there is an urgent need for effective conservation and management of deep-water fishery resources in the Northeast Atlantic.

\section{Acknowledgements}

We thank all members/participants of the ICES Study/Working Group on the Biology and Assessment of Deep-sea Fisheries Resources for their contributions in providing data and analyses used in this manuscript.

\section{References}

ANNALA, J. H. MS 1993. Report from the Fishery Assessment Plenary, May 1993: Stock Assessment and Yield Estimates. 241 p. (unpubl. report held in MAF Fisheries Greta Point Library, Wellington).
ANON. MS 1994. Report of the Study Group on the Biology and Assessment of Deep-sea Fisheries Resources. ICES C.M. Doc., No. Assess: 4, 91 p.

MS 1996. Report of the Study Group on the Biology and Assessment of Deep-sea Fisheries Resources. ICES C.M. Doc., No. Assess:8, 145 p.

MS 1998. Report of the Study Group on the Biology and Assessment of Deep-sea Fisheries Resources. ICES C.M. Doc., No. ACFM:12, 172 p.

MS 2000a. Report of the Study Group on the Biology and Assessment of Deep-sea Fisheries Resources. ICES C.M. Doc., No. ACFM:8, 206 p.

MS 2000b. Report of the Working Group on the Application of Genetics in Fisheries and Mariculture. ICES C.M. Doc., No. F:03, 53 p.

MS 2001a. Report of the ICES Advisory Committee on Fishery Management 2000. ICES Coop. Res. Rep., No. 242, 911 p.

MS 2001b. Report of the ICES Advisory Committee on Fishery Management 2001. ICES Coop. Res. Rep., No. 246, 895 p.

MS 2001c. Report of the Study Group on the Biology and Assessment of Deep-sea Fisheries Resources (by correspondence). ICES C.M. Doc., No. ACFM:23, $38 \mathrm{p}$.

BASSON, M., J.D.M. GORDON, P.A. LARGE, P. LORANCE, J.G. POPE, and B. RACKHAM. 2002. The Effects of Fishing on Deep-water Fish Species to the West of Britain. Joint Nature Conservation Committee Report No. 324. 150 p.

BEDDINGTON, J. R., and J. G. COOKE. 1983. The potential yield of fish stocks. FAO Fish. Tech. Pap., No. 242, 47 p.

BERGSTAD, O. A. 1995. Age determination of deep-water fishes; experiences, status and challenges for the future. In: Deep-water fisheries of the North Atlantic Oceanic Slope, A. G. Hopper (ed.). Kluwer Academic Publishers, The Netherlands, p. 267-283.

BERGSTAD, O. A., and N.-R. HAREIDE. 1996. Ling, blue ling and tusk of the north-east Atlantic. Fisken og Havet, 15, $126 \mathrm{p}$.

BERGSTAD, O. A., J. V. MAGNUSSON, J. MAGNUSSON, N.-R. HAREIDE, and J. REINERT. 1998. Intercalibration of age readings of ling (Molva molva L.), blue ling (Molva dipterygia Pennant, 1784) and tusk (Brosme brosme L.). ICES J. Mar. Sci., 55: 309-318.

BISEAU, A. 1998. Definition of a directed fishing effort in a mixed-species trawl fishery, and its impact on stock assessments. Aquat. Living Resour., 11 (3): 119-136.

BLASDALE, T., and A. W. NEWTON. MS 1998. Estimates of discards from two deep-water fleets in the Rockall Trough. ICES C.M. Doc., No. O:11, 18 p.

CHARUAU, A., H. DUPOUY, and P. LORANCE. 1995. French exploitation of the deep-water fisheries of the North Atlantic. In: Deep-water fisheries of the North Atlantic Oceanic Slope, A. G. Hopper (ed.). Kluwer Academic Publishers, The Netherlands, p. 337-356.

CLARK, M. R. 1996. Biomass estimation of orange roughy: a summary and evaluation of techniques for measuring stock size of a deep-water fish species in New Zealand. J. Fish Biol., 49 (Supplement A): 114-131. 
CLARK, M. R., O. F. ANDERSON, R. I. C. C. FRANCIS, and D. M. TRACEY. 2000. The effects of commercial exploitation on orange roughy (Hoplostethus atlanticus) from the continental slope of the Chatham Rise, New Zealand, from 1979 to 1997 . Fish. Res., 45: 217-238.

CLARK, M. R. 2001. Are deep-water fisheries sustainable? the example of orange roughy (Hoplostethus atlanticus) in New Zealand. Fish. Res., 51(2-3): 123-135.

CONNOLLY, P. L., and C. J. KELLY. 1996. Catch and discards from experimental trawl and longline fishing in the deep water of the Rockall Trough. J. Fish Biol., 49 (Supplement A): 132-144.

DUPOUY, H., V. ALLAIN, and B. KERGOAT. MS 1998. The discards of the roundnose grenadier in the French fishery in ICES Subareas VI and VII. ICES C.M. Doc., No. O:20, $10 \mathrm{p}$.

FENTON, G. E., S. A. SHORT, and D. A. RITZ. 1991. Age determination of orange roughy, Hoplostethus atlanticus (Pisces: Trachichthyidae) using ${ }^{210} \mathrm{~Pb}:{ }^{226} \mathrm{Ra}$ disequilibria. Mar. Biol., 109: 197-202.

FRANCIS, R. I. C. C. 1995. The problem of specifying otolithmass growth parameters in the radiometric estimation of fish age using whole otoliths. Mar. Biol., 124: 169-176.

GIRARD, M., P. LORANCE, and A. BISEAU. 2000. Captures par unité d'effort des espèces profondes du talus continental à l'ouest des îles britanniques. Cybium, 24 (3 suppl.): 97-104.

GORDON, J. D. M. MS 1998. Deep-water fish and fisheries in the northeastern Atlantic and Mediterranean: an overview of the EC FAIR Deep Fisheries Project. ICES C.M. Doc., No. O:10, 14 p.

GORDON, J. D. M. (ed.). 1999a. Developing deep-water fisheries: data for the assessment of their interaction with and impact on a fragile environment. Final Consolidated Report of European Commission FAIR Contract 95-0655, 1090 p. (also available as pdf file on www.sams.ac.uk).

GORDON, J. D. M. 1999b. Management considerations of deep-water shark fisheries. In: Case studies of the management of elasmobranch fisheries. R. Shotton (ed.). FAO Fish. Tech. Pap., No. 378: 774-818.

GORDON, J. D. M. 2001a. Deep-water fisheries at the Atlantic Frontier. Cont. Shelf Res., 21: 987-1003.

GORDON, J. D. M. 2001b. Deep-water fish and fisheries: introduction. Fish. Res., 51: 105-111.

GORDON, J. D. M., and S. C. SWAN. 1996. Validation of age readings from otoliths of juvenile roundnose grenadier, Coryphaenoides rupestris, a deep-water macrourid fish. J. Fish Biol., 49 (Supplement A): 289297.

GORDON, J. D. M., O. A. BERGSTAD, I. FIGUEIREDO, and G. MENEZES. 2002. Deep-water fisheries in the Northeast Atlantic. J. Northw. Atl. Fish. Sci., 31: 137-150 (this volume).

HEESSEN, H. J. L. (ed). MS 2001. Development of Elasmobranch Assessments DELASS-First Interim
Report. DG Fish Study Contract 99/055, 58 p.

JOHANNESSEN, A., and T. MONSTAD. 2003. Distribution, growth and exploitation of greater silver smelt (Argentina silus) (Ascanius) in Norwegian waters. J. Northw. Atl. Fish. Sci., 31: 319-332 (this volume).

KELLY, C. J., P. L. CONNOLLY, and J. J. BRACKEN. 1997. Age estimation, growth, maturity and distribution of the roundnose grenadier from the Rockall Trough. J. Fish Biol., 50: 1-17.

KOSLOW, J. A., G. BOEHLERT, J. D. M. GORDON, R. L.HAEDRICH, P. LORANCE, and N. PARIN. 2000. Continental slope and deep-sea fisheries: implications for a fragile ecosystem. ICES J. Mar. Sci., 57(3): 548-557.

LORANCE, P., and H. DUPOUY. 2001. CPUE abundance indices of the main target species of the French deepwater fishery in ICES Subareas V-VII. Fish. Res., 51(23): $137-149$.

LORANCE, P., F. GARREN, and J. VIGNEAU. MS 2001. Age estimation of the roundnose grenadier (Coryphaenoides rupestris), effects of uncertainties on ages. NAFO SCR Doc., No. 123, Serial No. N4511, 15 p.

MAGNÚSSON, J. V., O. A. BERGSTAD, N. R. HAREIDE, J. MAGNÚSSON, and J. REINERT. 1997. Ling, blue ling and tusk of the Northeast Atlantic. TemaNord, 535: $61 \mathrm{p}$.

MENEZES, G., A. ROGERS, H. KRUG, A. MENDONCA, B. STOCKLEY, E. ISIDRO, M. R. PINHO, and A. FERNANDES. MS 2001. Seasonal changes in biological and ecological traits of demersal and deep-water fish species in the Azores. Final Report, European Commission DGXIV/C/1 Study Contract 97/081, 162 p. + Appendices.

MERRETT, N. R., and R. L. HAEDRICH. 1997. Deep-Sea Demersal Fish and Fisheries. Chapman and Hall, London. $282 \mathrm{p}$.

MORALES-NIN B., and D. SENA-CARVALHO. 1996. Age and growth of the black scabbard fish (Aphanopus carbo) off Madeira. Fish. Res., 25: 239-251.

OSPAR. 2000. Quality Status Report 2000, Region V - Wider Atlantic. OSPAR Commission, London. 110 p.

SANTOS, A. M. P. MS 2000. Environment and biology of deep-water species Aphanopus carbo in the N.E. Atlantic: basis for its management (BASBLACK). Final Report of EC Study Project 97/0084, 94 p.

SMITH D. C., G. E. FENTON, S. G. ROBERTSON, and S. A. SHORT. 1995. Age determination and growth of orange roughy (Hoplostethus atlanticus): a comparison of annulus counts with radiometric ageing. Can. J. Fish. Aquat. Sci., 52: 391-401.

SWAN, S. C., J. D. M. GORDON, and T. SHIMMIELD. MS 2001. Preliminary investigations on the uses of otolith microchemistry for stock discrimination of the deep-water black scabbardfish (Aphanopus carbo) in the North East Atlantic. NAFO SCR Doc., No. 94, Serial No. 4482, 12 p. 